\title{
Effect of Selected Preoperative Factors on Postoperative Mortality in Dogs with Small Bowel Obstruction
}

M. CRHA, J. LORENZOVÁ, L. URBANOVÁ, T. FICHTEL, A. NEČAS

Department of Surgery and Orthopaedics, Small Animal Clinic, Faculty of Veterinary Medicine, University of Veterinary and Pharmaceutical Sciences Brno, Czech Republic

Received November 8, 2007

Accepted February 14, 2008

\begin{abstract}
Crha M., J. Lorenzová, L. Urbanová, T. Fichtel, A. Nečas: Effect of Selected Preoperative Factors on Postoperative Mortality in Dogs with Small Bowel Obstruction. Acta Vet. Brno 2008, 77: 257-261.

A total of 52 dogs surgically treated for small bowel obstruction were evaluated for selected preoperative clinical and laboratory findings as possible risk factors in regard to postoperative mortality in these patients. Relative risk of postoperative mortality was established for the following preoperative findings and indicators: leukocytosis or leukopaenia, anaemia, hypoalbuminaemia, hypocalaemia, thrombocytopaenia and bacterial peritonitis.

Of the selected preoperative factors, connection was demonstrated $(p<0.05)$ with hypoalbuminaemia, anaemia, thrombocytopaenia and bacterial peritonitis. On the other hand, preoperative findings of hypocalaemia, leukopaenia or leukocytosis were not associated in the monitored group of patients with a higher risk of postoperative patient mortality.

In clinical practice, preoperative assessment of the mentioned risk factors connected with a higher postoperative mortality rate could contribute to establishing a more accurate diagnosis in cases of the small bowel obstruction disease in dogs.
\end{abstract}

Small intestine obstruction, hypoalbuminaemia, anaemia, thrombocytopaenia, leukocytosis, leukocytopenia, hypokaliaemia, bacterial peritonitis, mortality

Small bowel obstruction in dogs is a relatively infrequent cause of the gastrointestinal tract disease, yet some long-term studies suggest an increasing tendency of the gastrointestinal tract disease with an obstructive cause (Koike et al. 1981; Böhmer et al. 1990; Capak et al. 2001). Unlike a whole number of non-obstructive diseases of the intestine, obstructive ileus is an unequivocal indication for surgical intervention. Surgical interventions related to the treatment of small bowel obstruction represent approximately 0.5 to $1 \%$ of all surgical procedures in dogs. With regard to the ethiopathogenity of obstruction, the mortality rate varies from $17 \%$ to $41 \%$ (Capak et al. 2001; Junius et al. 2004). Only a few clinical studies deal with the analysis of factors participating in the increased risk of complications in form of postoperative morbidity or mortality of patients with obstruction of the digestive tract in humans or animals (Jex et al. 1987; Allen et al. 1992; Wylie and Hosgood 1994; Ralphs et al. 2003).

While establishing prognosis in patients with small bowel obstruction, it is important to assess the case history and overall health condition of the patient. However, case history data given by the owner may not always be reliable. Therefore, it is necessary to rely mainly on clinical and laboratory examination and image diagnostics in the assessment of the patient's condition. Beside a thorough clinical examination, the laboratory examination of a blood sample not only provides information on the stability of the organism's inner environment but the analysis of some of its variables may indicate changes that are specific for the given disease. As basic haematological and biochemical blood examination is easily accessible in common practice, we decided to verify some links between selected preoperative findings (clinical and laboratory) and the obstructive disease of small bowel in dogs. 
The aim of this study was to find whether the selected preoperative factors (hypoalbuminaemia, hypocalaemia, thrombocytopaenia, anaemia, bacterial peritonitis, leukocytosis or leukopaenia) increase the mortality risk in patients with small bowel obstruction. We assume that the analysis of these preoperative factors could contribute to establishing a more accurate prognosis in cases of obstructive disease of small bowel in dogs. According to available data, a similar clinical study has not yet been published focusing on the above mentioned preoperative findings in relation to the risk of postoperative mortality in small bowel obstruction in dogs.

\section{Materials and Methods}

The clinical study included 52 patients treated for small bowel ileus, of the total number of 10,776 patients treated in the period from January 2003 to December 2005 at the Department of Surgery and Orthopaedics of the Small Animal Clinic of the University of Veterinary and Pharmaceutical Sciences in Brno. All patients underwent preoperative clinical examination, haematological and biochemical blood sample examination, as well as radiological and ultrasonographic examination of the abdominal cavity organs. Each patient was monitored for the occurrence of these preoperative factors: peritonitis (yes/no), anaemia (yes/no), leukopaenia or leukocytosis (yes/no), thrombocytopaenia - defined as a thrombocyte count $<200 \times 10^{9} / 1$ (yes/no), content of serum albumin $(\mathrm{g} / \mathrm{l})$ and potassium $(\mathrm{mmol} / \mathrm{l})$. Blood samples were taken from the patients' peripheral vein (v. cephalica antebrachii, v. saphena lateralis) before the initiation of any therapy. Surgical solution of the small bowel obstruction was done in general inhalation anaesthesia. The operational team consisted of the surgeon, an assistant and an anaesthesiologist. In all patients, the abdominal cavity was accessed by median laparotomy. In a given case enterotomy or enterectomy was performed according to the surgeon's decision, based on the subjective assessment of the intestinal wall vitality.

Each patient was repeatedly examined clinically during hospitalisation, and then on days 10 to 14 after the surgery during a follow-up for the extraction of skin sutures from the laparotomy incision. In case of a patient's death, autopsy was performed.

For statistical evaluation of qualitative indicators (peritonitis, anaemia, leukopaenia or leukocytosis) in the groups of patients $\chi^{2}$-test was used; for comparison of files of a small number of data Fisher's exact test was used (Göpfertová et al. 1999). All data were statistically evaluated and mutually compared using the programme Microsoft Excel 2002, SPSS 11.0.0., or SISA (Göpfertová et al. 1999).

\section{Results}

Of the total number of 10,776 patients treated at the Department of Surgery and Orthopaedics of the Small Animal Clinic from January 2003 until December 2005, patients with small bowel obstruction represented $0.48 \%$ of cases. Established deviations in the observed preoperative findings and indicators in 52 dogs with small bowel obstruction are presented in Fig. 1. Abnormalities were found in the group of these clinical patients within the scope of the monitored preoperative factors in the number of leukocytes (leukocytosis or leukopaenia) in 34 cases $(65 \%)$, anaemia in 10 cases $(19 \%)$, thrombocytopaenia in 8 cases $(15 \%)$, hypoalbuminaemia in 16 cases $(31 \%)$ and hypocalaemia in 13 cases $(25 \%)$. In 6 cases $(12 \%)$, preoperative bacterial peritonitis (Plate III, Figs 2 and 3) was diagnosed on the basis of cytological and biochemical examination of an effusion sample obtained by abdominal cavity puncture before the surgical intervention.

Results of the analysis of the effects of selected preoperative factors on the postoperative mortality rate are presented in Table 1 . Preoperative factors connected with a significantly higher risk of postoperative mortality $(p<0.05)$ included: peritonitis existing before surgery, thrombocytopaenia, anaemia, and hypoalbuminaemia (serum albumin level $\leq 20$ $\mathrm{g} / \mathrm{l}$ ). In contrast, preoperative findings of hypokalaemia, leukopaenia or leukocytosis were not associated with a higher risk of postoperative patient mortality in the studied group of patients.

\section{Discussion}

Factors accompanying higher postoperative morbidity or mortality in humans with gastrointestinal tract obstruction may be divided into preoperative, operative and 


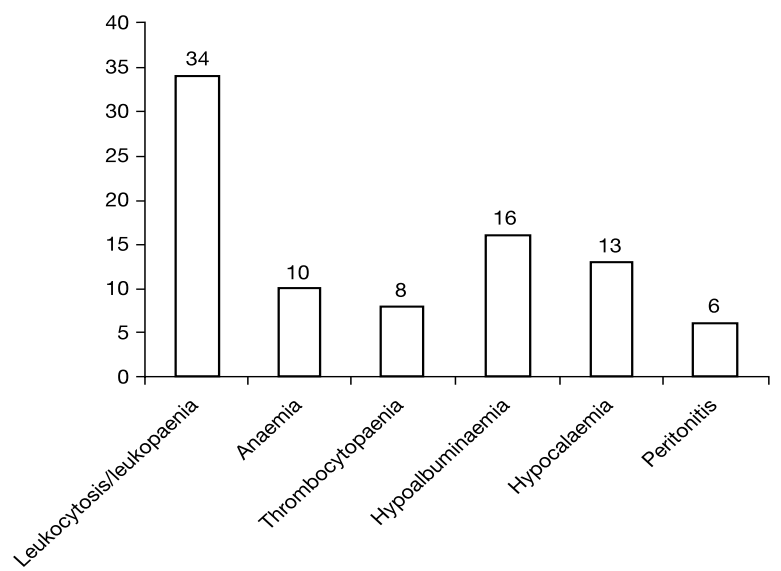

Fig. 1. Frequency of monitored preoperative factors in the group of $52 \mathrm{dogs}$ with small bowel obstruction.

Table 1. The effect of selected preoperative factors on the postoperative mortality rate in dogs with small bowel obstruction

\begin{tabular}{|l|c|c|c|}
\hline Preoperative factor & $\begin{array}{c}\text { Relative risk } \\
(\mathrm{RR})\end{array}$ & $\begin{array}{c}\text { Probability } \\
(p)\end{array}$ & $\begin{array}{c}\text { Reliability interval } \\
(95 \% \mathrm{RI})\end{array}$ \\
\hline Hypoalbuminaemia & 3.42 & 0.012 & $2.12-5.49$ \\
\hline Thrombocytopaenia & 8.0 & 0.002 & $2.86-22.36$ \\
\hline Anaemia & 4.4 & 0.028 & $1.82-10.59$ \\
\hline Peritonitis & 6.53 & 0.003 & $2.16-19.70$ \\
\hline *Hypocalaemia & 0.85 & 0.430 & $0.14-4.97$ \\
\hline *Leucopenia/leukocytosis & 1.35 & 0.420 & $1.13-1.62$ \\
\hline
\end{tabular}

Explanations: *Statistically non-significant $(p>0.05)$

postoperative (Jex et al. 1987; Allen et al. 1992). Preoperative factors include e.g. concurrent systemic disease of the cardiovascular apparatus, diabetes mellitus, treatment with corticosteroids, peritonitis, sepsis, hypoproteinaemia, hypoalbuminaemia, higher content of urea, neutrophilia, anaemia, etc. (Schrock et al. 1973; Irvin and Goligher 1973). Operative risk factors include long-lasting surgical intervention, shock, hypotension, hypovolaemia, operating field contamination, use of intra-abdominal drains, or transfusion administration (Golub et al. 1997). Postoperative risk factors include the duration of hospitalization, postoperative transfusion administration, bacterial peritonitis, necessity of supporting nutrition, etc. (Golub et al. 1997).

In our group of patients with small bowel obstruction, only selected preoperative factors were studied and on the basis of the statistical analysis of these factors, their link with the risk of postoperative mortality was evaluated. Patients with the occurrence of preoperative peritonitis, hypoalbuminaemia, thrombocytopaenia or anaemia demonstrated a significantly higher risk of the occurrence of complications in form of postoperative mortality.

Ralphs et al. (2003) published a study dealing with the analysis of risk factors associated with the dehiscence of intestinal anastomosis in dogs and cats. The dehiscence of the surgical incision led to the development of postoperative bacterial peritonitis accompanied by a high postoperative mortality rate $(85 \%)$.

Leukocytosis with a leftward shift was evaluated in this study as one of the risk factors associated with the dehiscence of the intestinal wall suture accompanying a 
high postoperative mortality rate. However, this fact was not unambiguously confirmed by the results of our study. In contrast, thrombocytopaenia was in our observations a significant $(p<0.005)$ preoperative risk factor associated with postoperative mortality occurrence. Patients with preoperative thrombocytopaenia demonstrated an eight times higher risk of postoperative mortality compared to patients without preoperatively proven thrombocytopaenia (Table 1).

The analysis of these factors may be beneficial for clinical practice for several reasons. For one, it allows the veterinarian to inform the owner more accurately on the prognosis of the disease, and it may also contribute to the estimate of possible therapy costs. Last but not least, the finding of some risk factors before surgery may alert to the necessity of initiating appropriate therapy sooner than fatal complications develop that may even lead to possible patient death.

It may be concluded that the preoperative factors that demonstrably participated in the risk of increased postoperative mortality included hypoalbuminaemia, anaemia, thrombocytopaenia and bacterial peritonitis. In contrast, findings of hypocalaemia, leukopaenia or leukocytosis did not significantly increase the postoperative mortality rate in the monitored group of patients.

The study has established relative risks of postoperative mortality in the monitored factors, which may be used in practice to determine a more accurate prognosis before surgery in patients with small bowel obstruction. We assume that a timely treatment initiation leading to the elimination of these risk preoperative factors may significantly decrease postoperative mortality accompanying surgical interventions in the obstructed small bowel.

\section{Vliv vybraných předoperačních faktorů na pooperační mortalitu u psů s obstrukcí tenkého stř̌eva}

V souboru 52 chirurgicky léčených psů s obstrukcí tenkého střeva byly hodnoceny vybrané předoperační klinické a laboratorní nálezy jakožto možné rizikové faktory z hlediska pooperační mortality u těchto pacientů. Bylo stanoveno relativní riziko pooperační mortality u následujících předoperačních nálezů a ukazatelů: leukocytóza či leukopénie, anémie, hypoalbuminémie, hypokalémie, trombocytopénie a septická peritonitida.

Z vybraných předoperačních faktorů byla s ohledem na vyšší riziko pooperační mortality psů s obstrukcí tenkého střeva prokázána souvislost $(p<0,05)$ s hypoalbuminémií, anémií, trombocytopénií a septickou peritonitidou. Naproti tomu předoperační nálezy hypokalémie, leukopénie či leukocytózy nebyly ve sledovaném souboru pacientů spojeny $\mathrm{s}$ vyšším rizikem pooperační mortality pacientů.

V klinické praxi by předoperační zhodnocení uvedených rizikových faktorů souvisejících s vyšší pooperační mortalitou mohlo přispět ke stanovení přesnější prognózy případů obstrukčního onemocnění tenkého stř̌eva u psů. Včasné zahájení léčby vedoucí k jejich eliminaci by pak mohlo významně snížit mortalitu provázející chirurgické zákroky na tenkém střevě s obstrukcí.

\section{References}

ALLEN DA, SMEAK DD, SCHERTEL ER 1992: Prevalence of small intestinal dehiscence and associated clinical factors: a retrospective study of 121 dogs. J Am Anim Hosp Assoc 28: 70-76

BENNETT RR, ZYDECK FA 1970: A comparison of single layer suture patterns for intestinal anastomosis. J Am Vet Med Assoc 157: 2075-2080

BÖHMER E, MATIS U, ZEDLER W, HANICHEN T 1990: Dünndarmileus bei Katze und Hund - katamnestische Betrachtungen von 704 Patienten. Tierarztl Prax 18: 171-183

CAPAK D, SIMPRAGA M, MATICIC D, BALI R, JANOSKA B 2001: Incidence of foreign-body-induced ileus in dogs. Berl Munch Tierarztl Wochenschr 114: 290-296

GOLUB R, GOLUB RW, CANTU RJR, STEIN HD 1997: A multivariate analysis of factors contributing to leakage of intestinal anastomoses. J Am Coll Surg 184: 364-372 
GÖPFERTOVÁ D, HLADÍKOVÁ M, ŠEJDA J, HROBOŇ P 1999: Epidemiologie. $1^{\text {st }}$ ed. Vydavatelství Univerzity. Palackého v Olomouci, pp. 442-443

IRVIN TT, GOLIGHER JC 1973: Aetiology of disruption of intestinal anastomoses. Br J Surg 60: 461-464

JEX RK, VAN HEERDEN JA, WOLFF BG, READY RL, ILSTRUP DM 1987: Gastrointestinal anastomoses. Factors affecting early complications. Ann Surg 206: 138-141

JUNIUS G, APPELDOORN AM, SCHRAUWEN E 2004: Mesenteric volvulus in the dog: a retrospective study of 12 cases. J Small Anim Pract 45: 104-107

KOIKE T, OTOMO K, KUDO T, SAKAI T 1981: Clinical cases of intestinal obstruction with foreign bodies and intussusception in dogs. Jpn J Vet Res 29: 8-15

RALPHS SC, JESSEN CR, LIPOWITZ AJ 2003: Risk factors for leakage following intestinal anastomosis in dogs and cats: 115 cases (1991-200). J Am Vet Med Assoc 233: 73-77

SCHROCK TR, DEVENEY CW, DUNPHY JE 1973: Factors contributing to leakage of colonic anastomoses. Ann Surg 177: 513-518

WYLIE KB, HOSGOOD G 1994: Mortality and morbidity of small and large intestinal surgery in dogs and cats: 74 cases (1980-1992). J Am Anim Hosp Assoc 30: 469-474 
Plate III

Crha M. et al.: The Effect ... pp. 257-261

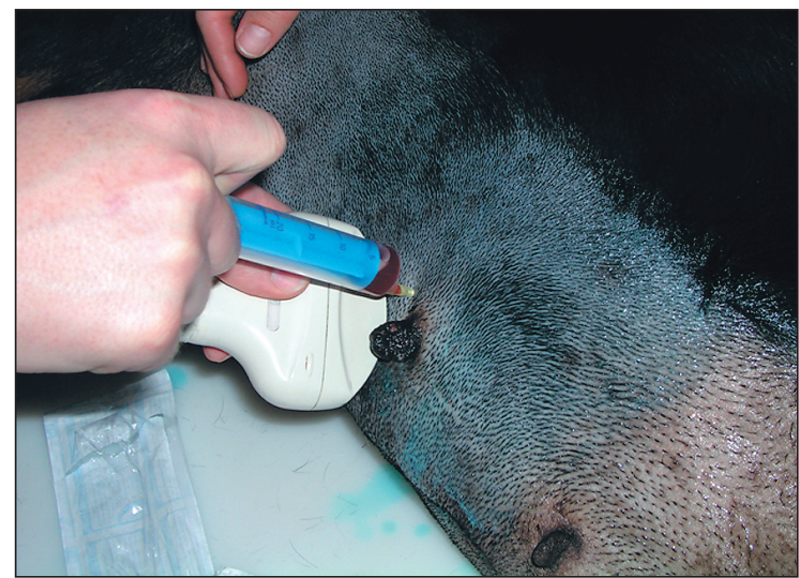

Fig. 2. Samplig of abdominal cavity effusion by abdominocentesis under ultrasonographic control.

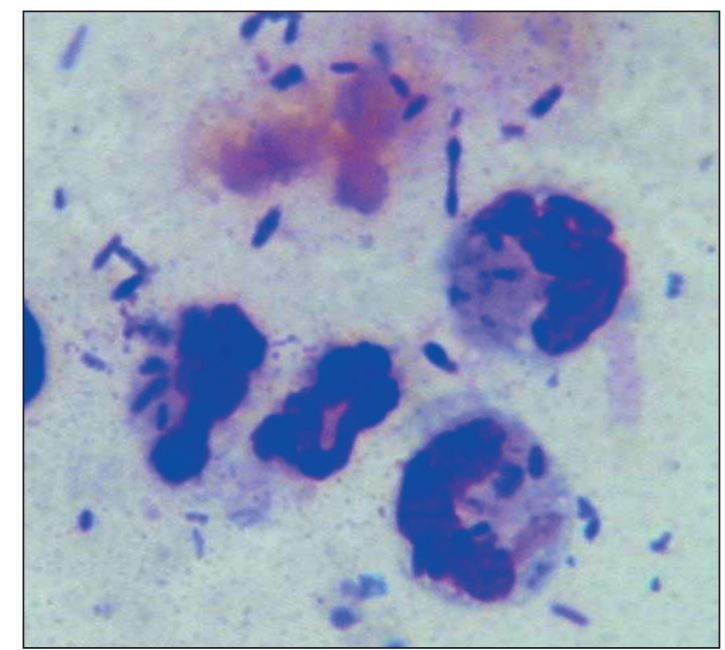

Fig. 3. Cytological smear of the effusion sample stained with the Diff-Quick method. Degenerated neutrophils with both phagocyted and free bacteria. 